\title{
IN HOEVER BEHOORT SENDING TOT DIE WESE VAN DIE KERK?
}

Behoort sending tot die wese van die Nieu-Testamentiese kerk of is dit ' $n$ insidentele saak wat nie wesenlik noodsaaklik is vir die bestaan van die kerk nie en bloot afhanklik van bykomende faktore wat van plek tot plek en van tyd tot tyd verskil? Die vraag is dus of 'n kerk wat geen missionêre roeping uitoefen nie, nog werklik kerk van die Here is. Verder moet ook gevra word of die hele wese van die kerk deur sending bepaal word as sending wel wesensbelangrik vir die kerk is. Is daar nie ander wesensfunksies wat gelykelik saam met die sending weeg nie?

\section{Aan die begin gemeente-sending:}

Aan die begin van die Christelike kerk na Pinkster was dit nie so dat sending beperk was tot die aktiwiteit van die apostels nie, maar dit was 'n saak van die hele gemeente. Die apostels wat met besondere gesag beklee was, het slegs met daardie gesag gesorg dat die grondleggende werk vir die kerk verrig word, maar verder het hulle arbeid nie verskil van die sendingarbeid van die ge meente nie. Dit blyk besonder duidelik uit die gemeente van die Thessalonicense. Die gemeente het besonder kragtig gewerk om die evangelie te versprei, want Paulus maak melding van hoe die evangelie van hulle af weerklink het oor die hele Macedonië en Achaje en hoe almal van hulle geloof spreek. Hieruit kan egter nog nie gekonkludeer word dat sending wesenlik is vir die kerk nie, want sowel die apostolaat as die eerste gemeentes was van verbygaande aard.

Die eerste Christelike kerk was homself sterk bewus van die onderskeid met die wêreld. Hulle was die uitverkorenes van God. Hulle bestaan was dus ook ' $n$ voortdurende getuienis vir die wêreld.

Die gemeente het 'n taak gehad in die omgewing waarin hulle was. Hulle moes hulleself heilig in alle fasette van die lewe. Hulle moes 'n nuwe lewe leef wat deur wederliefde vir God gekenmerk word. Die nuwe lewe moes egter geen tot hulleself ingekeerde lewe wees nie, maar dit moes inwerk op die omgewing. Dit moes die helende krag van die genade van God toon. Alle mense moet die sagmoedigheid, nederigheid, ens., van die gelowiges ken. Hulle gehoorsaamheid aan die owerheid, hulle blydskap, het krag na buite gehad. Uit hulle lewe moes iets van Christus straal en so het die missionêre aspek al die hele lewe van die kerk deurstraal. Hulle moes 'n lig en 'n suurdeeg wees.

\section{Spontane sending:}

Het die apostels nou opsetlik die gemeente ook opgeroep tot missionere arbeid? Omdat die sendingroeping spontaan begryp en uitgevoer is deur die gemeente het die apostels nie dikwels nodig gehad om op te roep tot sendingarbeid nie. Daar was meer nodig 
dat hierdie spontane arbeid in sy wyse van uitvoering deur die apostels gerig sou word. Hulle word herinner aan die selfverloënende arbeid van die apostels wat weer volgens die voorbeeld van Christus is. Met die selfverloëning in die arbeid moet ook gepaard gaan die fierheid en krag want Christus is ook Triomfator. Om bereid te wees om te getuig, beteken om bereid te wees om die kruis te dra (1 Petr. $3: 15$ v.v.). Ook in die gewone lewenstaak moet daar die bereidheid wees om die kruis te dra. Die apostels prys ook diegene aan wat aktief is met die Woord van die Here of die blye boodskap (Rom. $1: 8$, Fil. $1: 5,1$ Thess. $1: 7$ v.v.). So is dit duidelik dat volgens die mening van die apostels dit heel natuurlik is dat die gemeente missionêr sal wees.

Dit is duidelik dat die logos toe kurioe voorop staan in die missionêre arbeid van die eerste Christelike kerk. Maar die handel en wandel gaan hiermee altyd gepaard. Dit kan die koms van die Woord voorberei of dit bevestig. Christus self het deur sy Gees die Woord bevestig. Elke gemeentelid, ondanks verskeidenheid in gawes, het die taak om missionêr werksaam te wees. Elke aspek van die gemeentelike lewe het ook 'n missionêre sy. Veral die samekomste in die eredienste het verkondigend na buite uitgewerk. Die gemeente het ook 'n taak gehad t.o.v. alle mense met wie hulle in aanraking gekom het. Hulle kon ook nie rus voordat die eindes van die aarde bereik is nie.

\section{Die sendingmotiewe:}

Watter motiewe het nou die Christelike kerk gedring tot die sendingarbeid? Ten eerste het die ontfermende liefde van Christus die gemeente gedring tot wederliefde wat uiting gevind het in die vervulling van 'n sendingroeping, want hulle is gedring om oor hulle Verlosser te spreek. So sou Hy meer lof en aanbidding ontvang. Hulle het ook navolgers van Christus geword in die ontferming vir die verlorene. Omdat die liefde van Christus aanneem sonder verdienste van die aangenomene was daar ook by die Christene die regte ootmoed.

'n Tweede motief was dat Christus as die verhoogde Here regeer. Alles moet onder sy heerskappy kom.

Ten derde was ' $n$ motief vir die sending die verwagting van die volle heil, van die volheid van die koninkryk van God. Die volle koms van die koninkryk kon eers plaasvind wanneer die evangelie alle volke bereik het. Dit het die gemeente ook gedring.

Dis dus duidelik dat dit nie bykomstige faktore was wat die gemeente tot sending gedring het nie, maar die mees sentrale faktore van die Christelike geloof. „De liefde waardoor zij leeft, de heerschappij waaronder zij leeft, en het heil, waarheen zij leeft, moeten de gemeente bewegen om van Christus te getuigen tot elk, die de knie voor Hem nog niet buigt".' Die sending is gefundeer in die ewige raad van God waarin die besluit lê oor sy uitverkorenes. In opdrag van Christus word dit uitgewerk as Hy die apostels stuur soos Hy gestuur is en wanneer Hy die sendingbevel gee. 


\section{Sending behoort tot die wese van die kerk:}

So is dit duidelik dat sending werklik tot die wese van die kerk behoort. Dit is telkens die band aan Christus self wat tot sending bring. Omdat die gemeente gemeente van Christus is, is dit sendende (missionêre) gemeente. Hierdie eienskap is gegee met die bestaan van die Christelike kerk.

Die missionêre getuienis klink sterk juis wanneer die kerk deur verdrukking volhard. Die missionêre selfverloëning is met geen enkele ander nie-Christelike lewenshouding te vergelyk nie. In hierdie selfverloëning is dit nie humanisme wat bepalend is nie, maar die eer van God. Midde in die selfverloëning en verdrukking weet die kerk tog dat dit oorwinnaar is en is daarom nooit swak nie. Christus is onder alle omstandighede Koning.

\section{Die plek van die sending:}

Watter plek beklee die sending nou in die geheel van die wese van die kerk? H. Kraemer en A. A. van Ruler en veral Hoekendijk sê dat sending die enigste bestaansrede is vir die kerk. ${ }^{2}$

In baie van die briewe van Paulus word die sendingtaak glad nie of slegs weinig aangeraak. Dit dui daarop dat die sendingtaak een van ander en nie die allesbeheersende taak is nie. Die liefde tot Christus dring ook tot aanbidding sonder dat die oog gerig is na buite. Die gemeente moet bestaan as gemeente wat reeds in beginsel die gawes geniet wat hulle in Christus ontvang het. Hulle staan dus reeds in die poorte van die ewige heerlikheid en dien die Here reeds met 'n voorsmak van wat in die ewige heerlikheid sal wees. Die kerk is die voorlopige realisering van die nuwe mensheid van die toekomende eeu.

Uit die brief aan die Efesiërs is dit duidelik dat in die kerk die eenheid en die volheid onder die nuwe Hoof, Christus gerealiseer word. Die gemeente is die liggaam van Christus - die pleroma in opbou. Die pleroma is die einddoel van God en dit is nou reeds in opbou in al die geledinge van die kerk (Van Swigchem). Om die volheid te kan bereik moet daar groei wees wat deur missionêre arbeid tot stand kom, maar ook opgroeiing in die geloof, in heiligmaking. In die opgroeiing lê daar al meer genieting van die dinge van die volheid waarheen die kerk hom uitstrek. Sodra daar eensydig na die volle genieting vir sigself vooruitgegryp word, kom daar verstarring. As die eensydigheid na die ander kant gaan, kom daar eiewillige aktivisme en word die kerk innerlik swak en krampagtig.

So is die kerk dan meer as net missionêr wat sy wese betref. Kraemer het hom reaksionêr uitgespreek teen die neiging van die kerk om in homself gekeerd te raak. Brillenburg Wurth spreek van die apostolaat, die bestemming van die kerk. Met apostolaat bedoel hy dan die missionêre arbeid. Maar missionêre arbeid kan nie met die woord apostolaat aangedui word nie. Die grondbetekenis daarvan is wel "uitgestuur word", maar daar is die betekenis van 
die woord vereng om die werk van die apostels wat in die begin grondleggend was, aan te dui. Die gemeente moes missionêr aktief wees, maar nie apostolies nie. Ook die woord bestemming is nie 'n goeie keuse nie, want bestemming van die kerk het betrekking op die eindstaat waarin die kerk wil en moet verkeer en dit dui nie die werksaamheid van die kerk t.o.v. die ongekerstende wêreld aan nie. Behalwe dié terminologiese besware is daar ook nog beswaar teen die formulering van Brillenburg Wurth omdat dit in wese nie veel verskil van Kraemer nie. Immers dit gaan by hom ook om die werk wat die kerk t.o.v. die mons en die wêreld moet doen. Dat 'n volk ter wille van God vergader is, staan dan weer op die agtergrond. (Hierdie belangrike leemte is miskien ook merkbaar in die sendingorde van die N.G. Kerk. $)^{3}$

Hoekendijk spreek in degraderende toon van die kerk as slegs vehikel te wees van die koninkryk. So is die kerk dan in diens van die wêreld. Hierby word veral die plek van die kerk ontken as kerk wat missionêr aktief moet wees volgens Gods Woord en in wie die resultaat van die missionêre arbeid geïnkorporeer moet word. Omdat die praktyk vandag so oorweldigend sterk teen die kerk is, mag die kerk nie van geringe waarde beskou word nie.

Van Swigchem sou die missionêre aspek wou beskryf as een van die twee aspekte van die wese van die kerk in hierdie bedeling. Eksegese bevestig egter nie hierdie presiese omskrywing nie, en daarom volstaan hy deur te sê dat die sendingaspek 'n wesenlike aspek van die kerk is. Ons staan voor dieselfde probleem van oorvereenvoudiging wanneer ons net sou spreek van bewaring en vermeerdering en daarmee die totale aktiwiteit en wese van die kerk wil omvat.

Prakties beteken die konklusie wat uit die N.T. getrek is, nl. dat sending tot die wese van die kerk behoort, dat sending ook vandag nog normatief vir die kerk is. Sending moet ook vandag altyd en in alle dele van die kerk aanwesig wees. Dit is ook moontlik want in die wêreld met sy ontwikkelde kommunikasie is elke gemeente daagliks gekonfronteer met die wêreld. Dit kan missionêr besig wees op twee wyses: Deur die lewe van die kerk in die wêreld en deur die positiewe aksie wat van die kerk en sy lede uitgaan tot die wêreld. Van Swigchem beweer dat die Reformasie die sendingtaak nouliks raakgesien het. Wanneer in aanmerking geneem word dat ' $n$ groot deel van die reformasie self as missionêre arbeid gekenmerk kan word, is ons geneig om die reformatore minder kwalik te neem. Art. 7 van die Dordtse Kerkorde spreek van missionêre arbeid, al is dit onder die afgedwaalde Roomse. Evangelisasie en sending lê soms in die praktyk baie naby aan mekaar en praktiese omstandighede kan die kerk dwing om hom meer op die een of die ander toe te spits.

\section{Grondtrekke van die N.T.-sending:}

Die besonderhede van die sendingwerk wat in die N.T. na vore kom, is nie alles normatief nie. Dit dui egter wel die yrondvorme aan. 
Tot hierdie grondtrekke behoort die volgende:

1. Die hele gemeente moet sendingkerk (missionêre kerk) wees. Met die eie gawes moet elkeen op 'n eie plek werk. So is die gemeente ook weer die een liggaam van Christus wat met een werk besig is.

2. In die organisasie van die kerk sal met die sending rekening gehou moet word. Die prediking, die erediens, die diens van barmhartigheid, die pastoraat, die kerklike tug ens., moet alles op die een of ander wyse verbondenheid aan die missionêre aspek van die kerklike lewe bly vertoon.

3. Waar spesialisasie nodig is, moet die band met die gewone kerklike lewe tog behou word.

4. In navolging van Christus moet die gemeente weer veel meer selfverloënend wees.

5. Ootmoedig bewus van eie sonde moet die kerk tog die groot onderskeid tussen kerk en wèreld duidelik sien. Die genade van God vir hulle het hierdie onderskeid meegebring. Die antitese van die verkiesing bly die fondament van die sending.

6. 'n Duidelike belydenis is vir die kerk noodsaaklik vir sy arbeid t.o.v. die wêreld.

7. In die uitoefening van die sendingroeping sal die kerk sy krag steeds moet put uit die genieting van die gemeenskap met Christus.

8. Deur al die lewensuitinge sal die kerk die beeld van Christus moet vertoon.

9. Die opbloei van die sendingwerk sal sterker wees as die eskatologiese ingesteldheid van die kerk versterk word (Vgl. Van Swigchem).

Die regte missionêre houding is alleen moontlik deur die noue verbintenis aan Christus deur die Heilige Gees. Daarom moet by die Skrif geleef word en is voortdurend gebed nodig. Omdat Christus die groot apostel en die boodskap is, daarom moet sy kerk wat sy liggaam is, sending doen.

\section{Kerk en sending na die Reformasie:}

Daar is reeds verwys na die feit dat die sendingroeping deur die reformatore nie so duidelik gesien is nie. In die eeue wat gevolg het, het dit voortgaande invloed gehad op die kerk. Die groot sendingontwaking het daarom nie gekom deurdat die kerk sy roeping reg verstaan het nie, maar deur individue wat georganiseer het. Sedert die sendingkonferensie van Edinburg in 1910 het daar in toenemende mate begrip gekom vir die plek wat die kerk moet beklee in die sending. Teen die tyd dat die sendingkonferensie van Madras in 1938 gehou is, het groter helderheid bestaan oor die plek van die kerk. Deur die oorlog wat toe gekom het, is die insig nie dadelik ingedra in die sendingwerklikheid nie. In 1947 is daar by Whitby nie verder gekom as by Madras in 1938 nie. Die begrip dat sending die werk van die kerk in die wêreld en aan die wêreld is, het egter nou gekom om dic toekoms te bepaal. Vir Willingen is 
gekies as tema: Die Sendingverpligting van die kerk. Kerk en sending het in die regte verhouding tol mekaar te staan gekom as gevolg van teologiese besinning. Dit het ook verder gevra vir nuwe teologiese besinning.

Die konferensie te Willingen het in baie met die eerste konferensie van die Wêreldraad van Kerke ooreengekom waar die kerk ook die sentrale tema van bespreking was. Andersen skryf dit aan die invloed van Hoekendijk op Willingen toe dat daar nie tot definitiewe standpunte oor die plek van die kerk in die sending gekom is nie. Vir Hoekendijk beteken dit verskraling en verarming wanneer die kerk meer in die sentrum van belangstelling kom. Die sending. werk word ook vereng wanneer dit van die kerk uitgaan. Die koninkryk word dan ingedruk in die kerklike grense of dit bly soos 'n veraf weerlig slegs eskatologies wink. Andersen merk op dat die verbintenis van sending aan die kerk 'n verskraling tot gevolg kan hê. Daarom sê hy dat sending slegs as 'n aktiwiteit van die kerk beskou kan word op voorwaarde dat die kerk self gedefinieer word in terme van sending. (Dit sou seker beteken dat die sending voortdurend as wesenskenmerk van die kerk gesien moet word). Hoekendijk wil nie hê dat die kerk uitgesluit moet wees uit alle sendingarbeid nie, maar dit moet nie die sentrale plek beklee nie. Hoekendijk sê dat nie die kerk nie maar die koninkryk in die sentrum moet wees.

Andersen meen dat in die tema vir die konferensie van Willingen ' $n$ belangrike prejudisering vervat is. Die konferensie het in gebreke gebly om ' $n$ algemeen-aanvaarde verklaring te gee van die sendingverpligting van die kerk. Andersen meen dus dat daar eers na die Skrif teruggegaan moet word voordat gespreek kan word van die sendingverpligting van die kerk. Daar moet dieper gegaan word om die sending te fundeer. Hierdie fundering kan net gevind word in die Self-openbaring van die Drie-enige God in Jesus Christus. Die kerk is nie die oorsprong van die sending nie, maar sending is die aktiwiteit wat die kerk insluit en opneem in sy diens. Sending het dan sy uitgangspunt nie in die kerk nie, maar by die kruis van Christus.

Die sending het so sy oorsprong in die Drie-enige God self: "Out of the depths of His love for us, the Father has sent forth His own beloved Son to reconcile all things to Himself, that we and all men might, through the Spirit, be made one in Him with the Father in that perfect love which is the very nature of God". ${ }^{4}$

\section{Sending ontstaan nie uit die kerk nie:}

Hoewel sending dus tot die wese van die kerk behoort, het dit nie sy oorsprong in die kerk nie, maar in die Drie-enige God. Die moontlikheid en die noodsaaklikheid van sending begin by die kruis omdat deur God se daad in Christus sy heerskappy oor hierdie wêreld gevestig moet word. God het Christus gestuur en Christus het gesê dat soos die Vader Hom gestuur het, stuur Hy ook sy dissipels. Fintlik is die kerk nooit sendende kerk nie, maar ge- 


\section{In die Skriflig}

stuurde kerk wat deelneem in die sending. Hierdie gedagte bots nie met die gedagte dat die kerk nie geheel en al in sending sy wese vind nie. God het met die kerk tweërlei voor - om dit dan tot twee te reduseer, wat Van Swigchem gevaarlik ag weens gebrek aan eksegetiese gronde - nl. dat die kerk as bestaande entiteit God sal verheerlik as volk van God wat moet oorgaan in die ewige volk van God en aan die ander kant as kerk wat na die wêreld moet uitgaan as missionêre kerk. Wanneer vasgehou word dat God agter die kerk is en dat Hy die kerk vir sy doel gebruik, dan is dit duidelik dat albei bogenoemde take tot die wese van die kerk kan behoort omdat die take eintlik agter die kerk in die Drie-enige God fundeer word. Dit sou te sterk gestel wees om te sê dat die kerk in die sending wat van die kruis uitgaan, ingesluit word - indien insluit hier beteken dat dit aan die kerk sy enigste $\sin$ gee. Indien dit egter so verstaan word dat God wat sending beveel die kerk daarvoor gebruik soos Hy sy verheerliking beveel en die kerk daarvoor gebruik, kan hierdie bewering van Andersen aanvaar word. Dan stem dit nie ooreen met die radikale standpunt van diegene wat die bestaansgrond van die kerk alleen in die sending vind nie.

Andersen kom tot die gevolgtrekking dat die ware aard van die kerk nie sonder sending verstaan kan word nie. Maar sending kan alleen waarlik sending wees as dit sending deur die kerk is.

J. van den Berg $\mathbf{s e}^{5}$ dat dit 50 jaar gelede nog so was dat sending beskou is as ' $n$ minder of meer belangrike aanhangsel van die kerk, maar vandag word algemeen erken dat sending tot die wese van die kerk behoort. In die O.T. word die volk van God al gesien as die lig van die nasies en die kerk in die N.T. is nie ommuur en afgesluit van die wêreld nie (1 Petr. 2 : 9).

Van den Berg waardeer Hoekendijk se kritiek teen eensydige kerksentrisme, maar beskou dié kritiek te radikaal aangesien die kerk ook voor en na die sendingarbeid bestaan. Hy meen dat Hoekendijk die volle rykdom van die kerk as liggaam van Christus nie verstaan nie. Newbigin merk op dat ' $n$ kerklose sending net so ' $n$ onding is as ' $n$ sendinglose kerk en as alles sending is dan word niks sending nie. In die beweging van soma na pleroma is die kerk as instituut ' $n$ onmisbare skakel. Van den Berg stel dit so: uitbreiding van die kerk is 'n stimulus vir sending. Die kerk moet die uiterstes van die aarde bereik. Dit is die drangrede vir sending. Gedurig is daar die versoeking dat die sending in diens kan geraak van die diesseitige glorie van die kerk. Sending is dan bloot planting van kerke en niks meer nie. Veral die Roomse Kerk staan vir hierdie gevaar bloot wanneer dit om die glorie van die kerk hier en nou en nie om die koninkryk en die eer van God self gaan nie. ${ }^{6}$

Die dwaling is dan hier nie so seer dat te swaar klem gelê word op die kerk nie, maar juis dat die rykdom van die begrip „kerk” nie besef word nie. Die kerk word losgemaak van Christus en word as 'n bloot menslike instelling gesien. Die kerk is nie in die wêreld om homself te red nie, maar deur die kerk red God die wêreld. Wat die sending betref, is die kerk instrument van Jesus Christus. 


\section{Van kerk na die eskatologiese volheid:}

Planting van kerke moet 'n motief wees in die sending, maar die oog moet gerig wees op die eskatologiese volheid van die ryk van God. In dié sin is die koninkryk in sy volheid bepalend vir die sendingwerk van die kerk. Die weg wat God verkies het waarlangs sy koninkryk moet kom, is dat die kerk die Woord sal uitdra na al die nasies. Voordat dit nie gebeur het nie, sal die volheid van sy ryk nie kom nie. In sy sendingwerk moet die kerk gebalanseerd gerig wees op hierdie einde. $\mathrm{Na}$ twee kante kan daar eensydigheid wees. Daar kan geen ag gegee word op die feit dat die einde kom en dat ons reeds in die laaste dae staan nie; aan die ander kant kan die einde en in verband daarmee die sending, op die spits gedryf word sodat daar 'n neiging sal wees om telkens die dag van die wederkoms te bepaal. In nie een van die twee gevalle tree die kerk dan reg op nie. Wanneer die eskatologiese onderbeklemtoon word, word die kerk swak in sy arbeid. Wanneer die eskatologiese op die spits gedryf word, word die kerk krampagtig. Die eskatologiese motief maak dat die kerk nooit rus kan vind in homself nie, maar streef na die volheid van die ryk van God.

\section{Kerk as sendingdoel:}

Roels bespreek die kerk as doel van die sending. ${ }^{7}$ Ons handel hier oor die sending in sover dit tot die wese van die kerk behoort, maar uit Roels se proefskrif is dit duidelik dat die kerk tot die wese van sendingwerk behoort. Daar is dus volgens die regte Skriftuurlike siening ' $n$ interaksie tussen kerk en sending: sending bring die kerk tot stand en die kerk het weer sending tot gevolg.

Roels sien die kerk as liggaam van Christus, as bruid van Christus en as 'n heilige tempel van die Here. Hierdie drie dinge beklemtoon dat die kerk nie net middel is nie, maar ook doel. Hoekendijk beklemtoon die instrumentele betekenis van die kerk en verloën die feit dat die kerk ook doel moet wees. Daarom spreek hy van die apostolaat van die kerk. Die kerk moet opgaan in die sendingwerk. Dit is sy volle wese. Wanneer die kerk genoem word liggaam van Christus, bruid van Christus of tempel van die Here, is dit nie so dat die kerk net as middel gesien word nie, maar is dit doel in sigself en self van wesenlike betekenis. Van Swigchem stel dit ook duidelik dat die kerk die volk van God is, nou en hier, wat eenmaal sy volle volk sal wees in die volheid van sy ryk.

Roels sê dat die uiteindelike doel van sending buite die grense van die geskiedenis val, maar binne die grense van die geskiedenis is die kerk self ook ' $n$ doel.

Vervolgens handel Roels dan oor die kerk as instrument van sending. Dit bring ons weer by die onderwerp: In hoever behoort die sending tot die wese van die kerk. Sending behoort tot die wese van die kerk omdat die oorwinning in Christus nie net iets van die verlede is nie. Dit is ' $n$ voortgaande oorwinning in die tyd en in hierdie voortgaande proses is dit roeping van die kerk om so te 
leef dat dit homself in en aan die wêreld as gered in Christus vertoon. So bevorder dit doeltreffend die sending van Christus. So word die wêreld verlos. Die Satan is oorwin, Christus is oorwinnaar, maar daar is 'n voortgaande stryd, want die ryk van die duisternis oefen nog veel mag uit in hierdie wêreld. Dat die uitverkiesing en die gevolglike roeping en toevoeging tot die kerk meebring dat die kerk hom sterk bewus sal wees van sy onderskeid van die wêreld, word ook deur Roels beklemtoon.

Die skrywer van die brief aan die Efesiërs het besondere openbaring ontvang. Dit moes geproklameer word sodat die veelkleurige wysheid van God bekend gemaak sou word aan die owerhede en magte deur die kerk. Die kerk word volgens die raad van God gebruik. Die vervulling van God se raad geskied deur die kerk as instrument. Deur die kerk word die veelkleurige wysheid van God bekend gemaak. Die kerk is volgens Ef. 3: 10 die getuie van God teenoor die magte van die duisternis. Die kerk getuig dat God oorwin het, dat die doel bereik is, dat Christus oorwinnaar was en is.

In Ef. 4: 1 doen Paulus 'n beroep op die kerk om sy rol te vervul m.b.t. die verlossingswerk van God. Vir die kerk is dit dus van groot belang om sy taak te verstaan m.b.t. die verlossingswerk. Die kerk moet die diepte van die openbaring in Christus verstaan en word so betrokke in die verdere arbeid van die Here. Ooreenkomstig die wysheid en insig wat die kerk het, moet dit ook werk. Die kerk verstaan nie net nie, maar ontvang ook die genade om volgens die kennis te leef.

Die klimaks in die gebed van Paulus nl. dat sy lesers vervul mag word tot die volheid van God $(3: 19)$ beteken ook dat dit 'n gebed is dat die kerk God sal verheerlik. Die eerste drie hoofstukke van Efesiërs toon duidelik dat die kerk voorwerp en instrument is van God se handele. Daarom bestee Paulus soveel aandag aan die lewe van die kerk wat as getuie vir die wêreld moet dien. Die kerk moet as eenheid optree, moet die een liggaam van Christus wees. Daar is verskeidenheid in die arbeid maar dit is die een liggaam wat arbei en aan wie gearbei word. Die lys van ampte in Ef. 4:11 dui almal daarop dat die kerk op sigself opgebou moes word, omdat die liggaam van Christus daarop dui dat die kerk op sigself ook doel van die kerk se arbeid moet wees. Die lys wat in Ef. 4:11 genoem word, bring tot die gedagte dat die verskillende gawes wat God aan elkeen gegee het ook tot opbou van die kerk gebruik moet word. Die rol van elke persoon vir die opbou van die kerk is dus belangrik. Roels maak die opmerking dat die rol van elke lid ook belangrik is vir die sending, maar dat dit dan nie deur die doen van elke lid hoef te wees nie, maar deur die wees van 'n lid van die kerk. Laasgenoemde ag hy van primêre belang. Dit het ook groter gevolge. Hiermee kan ons instem in sover dit inhou dat daar vandag ook in die kerk ' $n$ bewustheid moet wees van wat hy self is en dat daar bewustheid sal wees van die verskil met die wêreld en dat die verskil so sigbaar sal wees dat die kerk die wêreld sal roep tot bekering. "... the mission significance of the believer is not at all limited 
to those specific activities which can legitimately be classified as special ,mission' activities, but his entire existence in all of its varied aspects bears an ineradicable significance for the Christian mission". 8

Hierdie aspek van die sendingwerk word dikwels verduister deur die appèl op die verskaffing van spesiale sendingdienste. Kunsmatig word die twee geskei. Die werklikheid is dat die spesiale dienste nie kan bestaan as dit nie gedra word deur 'n ware Christelike getuigende lewe nie. Daarom is dit ook so dat die kerk nie rede moet wees vir die verwyt dat hy een ding verkondig en in sy bestaan iets anders weerspieël nie. Daarom roep Paulus ook op tot innerlike opbou sodat daar krag kan wees om na buite die regte getuienis te laat uitgaan. Die kerk moet die hoogste volmaaktheid bereik sodat dit des te beter God se getuie in die wêreld kan wees. In sover die kerk gebrekkig is, is ook die getuienis aan die wêreld gebrekkig. Die lewe van die heidene toon hulle vervreemding van God, so moet die lewe van die gelowiges die teenoorgestelde verkondig. Die nuwe mens moet getuig vir Christus. Hy is die nuwe mens en elke gelowige moet beeld wees van Hom. Die aflê van die oue mens en die beklee met die nuwe, is ' $n$ individuele daad, maar omdat die hele kerk dit doen, gaan daar weer 'n gesamentlike getuienis uit.

In Efesiërs 3-6 val die klem op die lewe van die gemeente wat as getuienis sal dien. Die getuienis met die woord is egter nie uitgesluit nie. Die bekende teks Ef. $6: 15$ word deur sommige verklaar as dat met die woord getuig moet word. Roels vereenselwig hom nie met hierdie eksegese nie. Paulus verwys na sy eie prediking as voorbeeld vir die Efesiërs. Roels toon ook aan dat Ef. 5: 11-14 nie op sending met die woord slaan nie.

Roels maak die gevolgtrekking dat die rol van die gemeente in die sending volgens Efesiërs in 'n belangrike mate vervul word deur hulle bestaan in die wêreld, hulle handel en wandel, die Christelike lewe. Hy wys egter tereg daarop dat Efesiërs nie die volle beeld beskryf nie. Trouens, in 1 Thess. 1 , om maar 'n voorbeeld te noem, is dit so dat die gemeente die Woord laat weerklink het.

Deur hierdie studie van Roels bewys hy dus dat sending tot die wese van die kerk behoort. Die kerk kan immers nie bestaan sonder om getuienis te laat uitgaan nie en die uitgroei tot die mate van ' $n$ volwasse man, bring mee dat hierdie getuienis sterker sal word. ${ }^{9}$

\section{Konklusie:}

Daar kan dus vandag gesê word dat algemeen standpunt geneem word dat sending nie die wese van die kerk is soos Van Ruler, Hoekendijk en Kraemer wil nie, maar dat sending wel tot die wese van die kerk behoort. Die fout van die apostolaatsteologie is dat die wese gesien word in ' $n$ wesenlike funksie van die kerk en nie in wat die kerk is nie.

Swartruggens.

M. A. Kruger. 
1 D. van Swigchem: Het Missionair Karakter van de Christelijke Gemeente, p. 246.

2 Ibid., p. 247.

3 Vgl. Art. 1.a. en 1.b. van die Algemene Sendingreglement vir die uitvoering van art. 53 K.O.

4 Wilhelm Andersen: Towards a Theology of Mission, p. 42, aangehaal uit Missions under the Cross, p. 189.

5 J. van den Berg: Constrained by Jesus' Love.

6 Vgl. J. H. Bavinck: Inleiding in de Zendingwetenschap.

7 Edwin D. Roels: God's Mission.

8 Ibid., p. 195.

9 Vgl. J. Ridderbos e.a.: De Apostolische Kerk en H. du Plessis: Die Missiologie as 'n Teologiese Wetenskap, wat vir hierdie artikel gebruik is. 